\title{
TASHKENT STATE UNIVERSITY OF LAW - YESTERDAY AND TODAY
}

\author{
Soburov Hasanjon Shavkatjon o'g'li \\ Master of Tashkent State Law University
}

\begin{abstract}
$\Lambda$
BSTRACT: This article is devoted to the history of the university, its role among the higher education institutions of the Republic, its role in the development of legal education, as well as the achievements of scientists, government officials, achievements over $\mathbf{3 0}$ years. Improving the spiritual and moral education of students also includes helping students to become full members of society, mature professionals in their profession through various forms, methods and means of education. At TSUL, students and teachers to ensure transparency in providing the digitalization of the educational process, including the formation of the training schedule, exams, evaluation, ranking of students in the formulation and implementation of the transition to electronic document exchange "Electonic university" providing information about the platform (e-University) data can be obtained. In addition, this article aims to improve the spiritual and moral education of students, to help students to become full members of society, professionals in their profession, to develop spiritual qualities in the minds and hearts of students, the idea of national independence and the ideology of independence. to help students spend their free time meaningfully, to form in young people a sense of national pride, patriotism and devotion, to study their worldview and interests.
\end{abstract}

EY WORDS: TSUL, public administration law, master's, bachelor's, distance education, jurisprudence, civil law, hybrid, electonic university, corruption, advocacy, business law, labor law, distance learning, evening education, legal tech, platform.

\section{NTRODUCTION}

Today, Tashkent State Law University, which is part of the Ministry of Justice of the Republic of Uzbekistan, is a state higher education institution and one of the centers of legal science in Uzbekistan. The capital of the Republic of Uzbekistan is located in Tashkent.

The University is a leading higher education institution recognized as one of the national centers of legal sciences and legal education in Uzbekistan. His prestige is widespread outside the Republic. Today, the university has 5 faculties, a Center for Legal Professional Development, a branch specializing in training and retraining of legal personnel in the field of crime prevention and public safety, a professional training center for international standards, a specialized branch of Tashkent State Law University and an academic lyceum. The University also provides methodological guidance and coordination on the activities of 14 legal technical schools included in the system of educational institutions of the Ministry of Justice. Rakhimjon Rasuljonovich Khakimov, Doctor of Law, has been the rector of Tashkent State University since 2019.

The history of the university dates back to April 21, 1918, when the Department of Law was established at the Turkestan People's University on the basis of the socio-economic faculty. From 1918 to 1990, this 
Oriental Journal of Education Vol.1 (1), pp.01-06, 30 May, 2021 Available online at http://www.supportscience.uz/index.php/oje (C) 2021 Support Science LLC

DOI: https://doi.org/10.37547/supsci-oje-01-01

department underwent a number of changes as an institution under the People's Commissariat of Justice of the USSR. On August 15, 1991, by the decision of the Council of Ministers of the USSR, the Tashkent State Law Institute was established on the basis of the Faculty of Law of Tashkent State University. The history of the university includes well-known scholars who have made an invaluable contribution to the development of the national law school in Uzbekistan and Uzbek jurisprudence - academicians Khojiakbar Rahmonkulov and Shavkat Urazaev, Boris Blind, Georgi Sargsyan, Shoakbar Shorahmetov, Gafur Abdumadjidov, Ikrom Zokirov and many others.

By the Decree of the President of the Republic of Uzbekistan No. PP-1990 of June 28, 2013, the Tashkent State Law Institute was transformed into the Tashkent State Law University, and the transition to a new modular education system gave a qualitatively new impetus to legal education. Today, Tashkent State Law University has 4,426 undergraduate and 269 graduate students. The rectors who have been working since the establishment of our university as an institute are:

- 1991-1993 - Anvar Azamovich Azamkhodjaev

-1993-1994 - Akmal Saidov

-1994-1995 - Shavkat Zakarievich Urazaev

- 1995-2001 - Boboev Halimboy

- 2001-2012 - Rustamboev Mirzayusuf Xakimovich

- 2012-2013 - Mukhamedjanov Amanulla Zakirovich

- 2013-2019 - Kanyazov Esemurat Sultamuratovich

- From 2019 to the present - Khakimov Rakhimjon Rasuljonovich

Education at the university is conducted in three languages: Uzbek, Russian and English. To study in English, a student must have an IELTS certificate, which determines the level of English proficiency, or an English language test at the university itself. Today, the university has 279 professors and teachers, 33 of whom have the degree of Doctor of Science (DSc), 82 Candidate of Science (including 29 Doctor of Philosophy (PhD)), 23 professors, 42 associate professors. The average age of candidates of science is 46 years, as well as the average age of persons with the degree of Doctor of Philosophy (PhD) in law is 34 years, the average age of doctors of science is 50 years. The university has a total of 17 doctoral students and more than 300 independent researchers. More than 10 of the independent applicants are foreign nationals.

The academic bachelor's degree in "Jurisprudence" prepares legal personnel in five specialties:

- State legal activity

- Civil law activities

- Criminal law activity

- International legal activity

- Entrepreneurial legal activity (business law)
The university cooperates with the military department of the National University of Uzbekistan. After studying at the military department of the National University of Uzbekistan, students will receive the rank of reserve lieutenant. Students of the jurisprudence program in the first year of study receive a comprehensive set of basic theoretical knowledge in the field of state and law.

From the second year of study, they master selected areas of law (depending on the profession) and some related disciplines: economics, political science, information and communication technologies. In addition, during the internship, graduates will gain the necessary practical skills to work in the future in the fields of law and law enforcement, advocacy, public authorities and law firms.

Courses taught: Constitutional Law, Administrative Law, Civil Law, Criminal Law, Labor Law, Environmental Law, Civil Procedure Law, Criminal Procedure Law, Financial Law, Criminology, Tax Law, International Law, Commercial Law, Land Law, Private Law development, the method of studying law, the written speech of a lawyer, and so on.

The educational process is conducted by highly qualified professors and teachers, including Doctor of Law, Academician A. Saidov, Honored Scientist of the Republic of Uzbekistan, Doctor of Law, Professor H. Boboev and others. There is a special type of compulsory internship for students in the educational process, in which students provide free legal assistance to the population under the guidance of teachers at the Legal Clinic of Tashkent State University. In it, the reception is held face to face. In addition, on the website of TSU (tsul.uz) "Legal clinic. Virtual reception "section has been opened.

The library is a separate structural unit of the university, covering many areas of activity (educational, scientific and spiritual-enlightenment) and actively participates in the educational, scientific and cultural processes of the university. The emergence and development of the Information Resource Center of the Tashkent State University of Law (IRC TSU) is directly related to the formation and development of legal education in Uzbekistan. Today, the library is an important part of the scientific information system of the Republic, which has a rich fund of 300,000 copies of books by national and foreign authors and periodicals. IRC also has a very rare fund. It includes 3,000 books, including the 1814 book "The First Foundations of Criminal Law" by Russian professor Ivan Neumann, "Al-hidoya fi sharhi Bidoya al-mubtadi" by the great thinker, jurist and Islamic jurist Burhaniddin al-Marghinani, or "Kitab ul- There is a 1893 copy of his commentary on Muslim law entitled "Hidoya," as well as a more than 100-volume set of laws of the Russian Empire. As of 2019, the University 
Oriental Journal of Education Vol.1 (1), pp.01-06, 30 May, 2021 Available online at http://www.supportscience.uz/index.php/oje (C) 2021 Support Science LLC

DOI: https://doi.org/10.37547/supsci-oje-01-01

Information Resource Center is a member of the International Association of German University Libraries in Dusseldorf.

The university has postgraduate education in the form of doctoral and independent research. Two scientific councils DSc.07 / 30.12.2019.Yu.22.01 and DSc.07 / 30.12.2019.Yu.22.02 work in the field of awarding academic degrees in the following specialties:

- 12.00.01 - Theory and history of state and law. History of legal doctrines

- 12.00.02 - Constitutional law. Administrative law. Finance and customs law

- 12.00.03 - Civil law. Business law. Family law. Private international law

- 12.00.04 - Civil procedural law. Economic procedural law. Arbitration process and mediation

- 12.00.08 - Criminal law, crime prevention. Criminology. Criminal-executive law

- The University has 3 scientific journals recognized as scientific publications by the Higher Attestation Commission under the Cabinet of Ministers of the Republic of Uzbekistan:

- "Legal Bulletin - Вестник юридических наук Review of Law Sciences"

- Journal "Analysis of the legislation of Uzbekistan Review of the legislation of Uzbekistan."

- TSUL Legal Report electronic journal

These journals include national databases such as DigitalCommons-Uzbekistan (www.uzjournals.edu.uz), Database of Scientific Publications (http: //uzscite.uz), as well as RINC and other international information intended for publication of the main results of scientific research. included in the databases. The Council of Young Scientists was established at the University to coordinate the scientific activities of young teachers, doctoral students and independent researchers and provide methodological assistance. More than 15 scientific circles organized at the university departments ("Academic", "Students business club", "Civilist", "Criminologist", "Lawyer-ecologists", "Procedure", "Labor rights activist", etc.) 1000 more gifted students were involved.

The University has worked closely with internationally recognized organizations such as QS (Quacquarelli Symonds World University Rankings), THE (Times Higher Education). During the 2019-2020 academic year, research is being conducted on 7 educational grants totaling 2.2 billion soums. In 2019, a total of 230 scientific articles were published in 44 international journals, 25 of which were included in Scopus and Web of Science international scientific and technical databases. Also, 28 monographs were prepared. In 2019, 14 copyrighted materials were certified by university professors. In addition, acts were received from relevant ministries and departments on the implementation of 23 research developments of professors and teachers.

The project "Innovative form of expanding access to legal education through the platform" Electronic University ", funded by the World Bank through the Fund for Academic Innovations (\$140,000). In addition, work is underway with the University of Gdansk in Poland and the University of Lund in Sweden on the EU Erasmus + grant project (\$ 200,000).

International cooperation of Tashkent State University is based on more than 30 agreements with higher education institutions, research centers and research institutes of Europe, Asia, America, as well as foreign embassies and international scientific and educational foundations. TSU's partner universities include Osaka and Nagoya Universities (Japan), Boston College School of Law (USA), UK Law University, German University of Administrative Sciences in Schpaer and the German Research Institute of Public Law Management, University of Regenburg (Germany), Shanghai Policy and Law University (PRC), Ural State Law University (RF), Polotsk State University (Republic of Belarus), Narikbaev Kazakh State Law University (Kazakhstan) and other universities. On September 7, 2005, the Center for the Study of Japanese Law and Language was opened at the University. The purpose of the center is to provide students with the opportunity to study Japanese law in Japanese and to develop proposals for improving the legislation of Uzbekistan, taking into account national characteristics, through a comparative analysis of the Uzbek-Japanese legal system.

In 2020, the Tashkent State Law University in cooperation with the University of Regenburg (Germany) plans to open a center of German law and comparative law. Within the framework of the signed Memorandums, students and teachers are being exchanged, joint research and advanced training is being carried out.

The University provides all the conditions for students to study, as well as play sports, grow creatively and improve themselves. In particular, the university has a modern gym, gym, coworking space, information resource center and more than 30 different clubs. The main educational building covers an area of 3504 thousand square meters and is located at 35 Sayilgoh Street. The building has 5 departments, 26 lecture and seminar rooms, the rector's office, the University Council Hall, administrative departments of the university, as well as the Legal Clinic. The second educational building of the university occupies an area of 6927 thousand square meters, it has 5 departments, 43 lecture and seminar rooms, a room for court hearings (Moot court), a forensic laboratory. It should be noted that these educational buildings are architectural monuments and were built in 1875 . The 
Oriental Journal of Education Vol.1 (1), pp.01-06, 30 May, 2021 Available online at http://www.supportscience.uz/index.php/oje (C) 2021 Support Science LLC

DOI: https://doi.org/10.37547/supsci-oje-01-01

third educational building of the University, located at 13 Amir Temur Street and with an area of 9557 thousand square meters, was transferred to TSU in 2013. After the overhaul, the building has 5 departments, 21 lecture and seminar rooms, 2 computer rooms. A modern sports complex is equipped to organize recreation and sports for students. The building also houses an Information Resource Center, which includes two conference halls, a bookstore, and reading rooms.

Tashkent State University has two 4-storey dormitories with a total area of 8972 square meters and 488 beds. Students live in comfortable single and double rooms. The dormitory provides students with all bedding. The building also has a kitchen, laundry room, fitness room, library and Wi-Fi zone.

In February 2019, the Tashkent State Law University established a Specialized Branch for the training and retraining of legal personnel in the field of crime prevention and public safety in Tashkent and Tashkent region. This branch trains personnel for the Ministry of Internal Affairs and the National Guard of the Republic of Uzbekistan. The Center for Professional Training of Legal Personnel on International Standards was established in 2018 to train legal personnel on the basis of international standards, which can adequately represent the interests of the Republic and the country's organizations in the international arena. The center operates in three directions:

- organization of short-term professional training of legal personnel based on international standards

- Legal retraining courses for people with higher education

- Retraining and advanced training of teachers in the field of "Law" and "Jurisprudence"

Legal training courses based on international standards are conducted by experts from international law firms such as White \& Case, Foley Hoag, Dentons, Sidley Austin, Vinson \& Elkins, Willkie Farr \& Gallagher, Hogal Lovels and Glassgow University. Students who successfully complete the courses will be sent to world-renowned law firms and international arbitration institutions for advanced training.

In accordance with the Decree of the President of the Republic of Uzbekistan dated April 29, 2020 "On additional measures to radically improve legal education and science in the Republic of Uzbekistan" PF-5987, the organizational structure of Tashkent State University was revised and new faculties and departments were established. Today, Tashkent State Law University has 5 faculties. Several new departments and centers have been established within these faculties, including the Department of Constitutional Law, the Department of Administrative and Financial Law, the Department of Judiciary, Law Enforcement and Advocacy, the Department of
Criminology and Forensics, the Center for Japanese Studies, German Law and Comparative Law. the research center is one of them. The university has 19 departments. As of February 2021, the university's scientific potential is $41.2 \%$. Over the next 5 years, measures are being taken to increase the scientific potential to at least $70 \%$ by supporting research.

The European Credit Transfer and Accumulation System (ECTS) was introduced, providing students with the opportunity to choose subjects.

The university is implementing joint educational programs aimed at awarding a "double degree".

In the framework of joint educational programs, an agreement was reached with the Grodno State University named after Yanka Kupala of the Republic of Belarus on the training of bachelors in international private law, and the Kazakh State University named after MS Narikbaev of the Republic of Kazakhstan on international economic law. Negotiations are also underway with Ankara's Boyazid Yildirim University and the University of Warsaw in Poland to establish joint educational programs.

In order to ensure transparency and convenience for students and teachers, Tashkent State University is launching an e-University platform, which provides for the digitization of the educational process, including the formation of schedules, examinations, assessments, student rankings and the transition to electronic document exchange. This platform allows students and their parents, the general public to monitor and directly participate in all processes related to the activities of the university, and ensures the openness and transparency of the processes.

Preventing and combating corruption is one of the main tasks of the university. In this regard, the University has adopted an Anti-Corruption Program. The Anti-Corruption Commission has been established. A code of ethics has also been developed. Mechanisms are being introduced to create a feedback system for receiving information on corruption facts, to conduct systematic surveys among students on corruption issues and to take practical measures based on their results, and to exercise public control over the examination process. TSU has been accepted as a full member of international organizations such as the International Association of Universities (IAU), the International Association of Law Schools (IALS), and the European Law Faculties Association (ELFA). Applications for membership in the Grand Charter of Universities (Magna Charter) and the European Association of Higher Education Institutions (EURAShE) have now been submitted.

Today, the Tashkent State Law University prepares staff for the following specialties with a training period of 1 year:

1. Advocacy 
Oriental Journal of Education Vol.1 (1), pp.01-06, 30 May, 2021 Available online at http://www.supportscience.uz/index.php/oje (C) 2021 Support Science LLC

DOI: https://doi.org/10.37547/supsci-oje-01-01

2. International arbitration and dispute resolution

3. Sports law

4. The right of public administration

5. Business law

6. Labor law

7. Theory and practice of application of criminal law,

8. Intellectual Property and Information Technology Law

On May 10 of this year, the Master's Department was reorganized into the Faculty of Master's and Part-Time Education. In this regard, the university structure was amended by order of the Minister. Also, on May 10, 2021, the relevant order of the rector of the University No 08-122 "On measures to further improve the activities of the Tashkent State Law University" was adopted. Our faculty consists of 3 departments. These are:

- General education sciences and culture;

- Uzbek language and literature;

- Departments of Physical Culture and Sports.

The faculty was removed from the subordination of the vice-rector and transformed into a structural unit directly subordinate to the rector. In case of admission of students to the faculty, it is planned to simultaneously combine 5 types of education and conduct the process of education and upbringing. These are:

1. Master's degree.

2. Distance education.

3. Evening education.

4. Postgraduate education (second specialty).

5. Distance education.

Our faculty is becoming a department operating in a hybrid system, which combines bachelor's and master's degrees. As far as we know, such a faculty is not found in our country.

Our university has announced the admission to independent research for 2021 in the following specialties:

12.00.01 - Theory and history of state and law. History of political and legal doctrines.

12.00.02 - Constitutional law. Administrative law. Finance and customs law.

12.00.03 - Civil law. Business law. Family law. Private international law.

12.00.04 - Civil procedural law. Economic procedural law. Arbitration process and mediation.

12.00.05 - Labor law. Social security law.

12.00.06 - The right to natural resources. Agrarian law. Environmental law.

12.00.07 - Judicial power. Procurator control. Organization of law enforcement activities. Advocacy.

12.00.08 - Criminal law. Crime prevention. Criminology. Criminal-executive law.

12.00.09 - Criminal proceedings. Forensics, forensic law and forensic science.
In 1918, TSU ARM first functioned as the library of Turkestan State University. In 1924 it was transformed into the library of the Faculty of Law of the Central Asian State University. In accordance with the Decree of the President of the Republic of Uzbekistan dated June 20, 2006 "On the organization of information and library services to the population of the Republic", the library was transformed into "Information Resource Center".

\section{ONCLUSION}

In conclusion, our faculty, which includes 5 aspects of education, is a source of pride and pride for all of us, on the one hand, and a huge responsibility on the other. We have before us the organizational work related to the formation of a new faculty, the exemplary organization of its activities. In the future, our university will definitely have an internationally recognized QS Quacquarelli Symonds World University Rankings (official website: www.topuniversities.com), THE-Times Higher Education (official website: www.timeshighereducation.com), ARWU - The Academic Ranking of World Universities (official website: http://www.shanghairanking.com) We are confident that it will be included in the list of the top 1000 universities in the ranking of higher education institutions published by the organization and whose educational documents will be recognized directly (without exams).

\section{EFERENCES}

1. Najimov M.K. State functions. - Tashkent: TSUL, 2018.- P.25.

2. Theory of state and law. Team of authors. Textbook / prof. Edited by HT Odilkoriev. Tashkent: Sharq, 2009. - B. 130; Islomov Z.M. Theory of state and law. - Tashkent: Adolat, 2007. - P.218.

3. Xakimov R. Innovation in Norma's creativity - starts a new era in the field // http: //parliament.gov.uz/uz/events/opinion/24179/sphra se_id=2545249 (2018)

4. See: Najimov MK, Saydullaev Sh.A. Legislative technique. Study guide. - T.: TSUL, 2008. - Б. 74.

5. Хропанюк В.Н. Теория государство и права. М.: Омега-Л, 2015.

6. Общая теория права и государство // Под ред. Лазарева В.В. - М.: Юристь, 2010.

7. Исломов 3. Общество. Государство. Право (Вопросы теории). - Т.: Адолат, 2001. -С.229.

8. Малько А.В. Субьективное право и законный интерес / Теория государства и права. -М.: 
Oriental Journal of Education Vol.1 (1), pp.01-06, 30 May, 2021 Available online at http://www.supportscience.uz/index.php/oje

(C) 2021 Support Science LLC

DOI: https://doi.org/10.37547/supsci-oje-01-01

Юристь, 2012.

9. Теория государства и права. Учебник / Ред.: В.М.Корельский, В.Д.Перевалов. 2-е изд.,изм. и доп. - М. : НОРМА-ИНФРА-М, 2002. - С.152153.

10. Теория государства и права. Учебник / Ред.: В.М.Корельский, В.Д.Перевалов. 2-е изд., изм. и доп. - М.: НОРМА-ИНФРА-М, 2002. -С.153.

11. Адилходжаева С.М. Глобализация и стратегия государства. - Ташкент: ТГЮИ, 2007.

12. Лукашук И.И. Глобапизация, государство, право, ХХИ век. - М., 2000.

13. www.tsul.uz

14. www.lex.uz

15. www.norma.uz

16. www.wikipedia.uz

17. www.natlib.uz

18. www.ziyo.uz

19. www.elibrary.ru 